\title{
Cellf- $9109.20--9$
}

LBL-31347

\section{LB Lawrence Berkeley Laboratory UNIVERSITY OF CALIFORNIA}

\section{CHEMICAL BIODYNAMICS DIVISION}

Presented at the Fourth Topical Meeting on Tritium Technology in Fission, Fusion and Isotopic Application, Albuquerque, NM, September 29-October 4, 1991, and to be published in the Proceedings

\section{Design and Operations at the National Tritium Labelling Facility}

H. Morimoto and P.G. Williams

September 1991

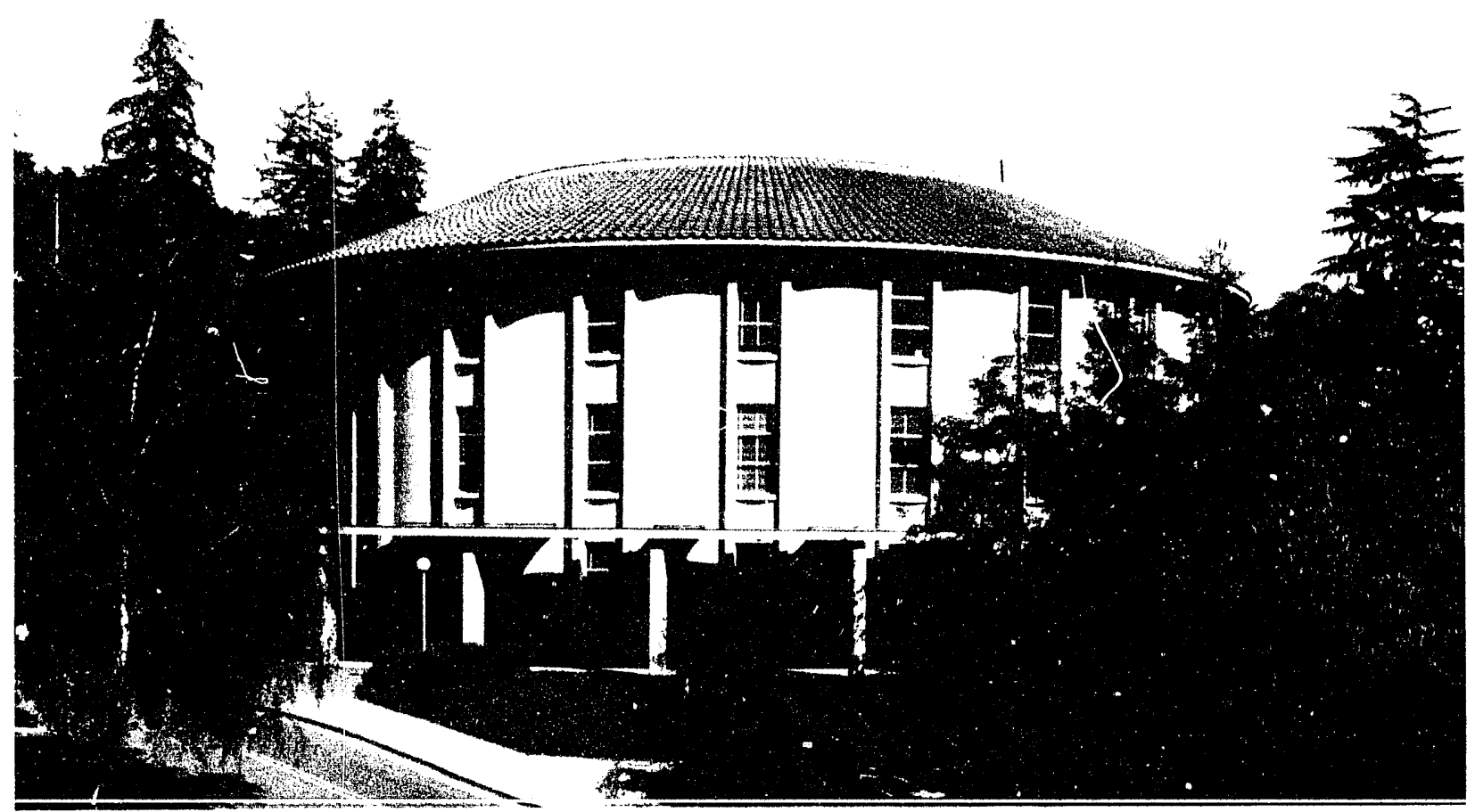

DISTAIBUTION OF THS DOCUMENT IS UNLIMITED

Prepared for the U.S. Department of Energy under Contract Number DE-AC03-76SF00098 


\section{DISCLAIMER}

This document was prepared as an account of work sponsored by the United States Government. Neither the United States Government nor any agency thereof, nor The Regents of the University of California, nor any of their employees, makes any warranty, express or implied, or assumes any legal liability or responsibility for the accuracy, completeness, or usefulness of any information, apparaius, product, or process disclosed, or represents that its use would not infringe privately owned rights. Reference herein to any specific commercial products process, or service by its trade name, trademark, manufacturer, or otherwise, does not necessarily constitute or imply its endorsement. recommendation, or favoring by the United States Government or any agency thereof, or The Regents of the University of California. The views and opinions of authors expressed herein do not necessarily state or reflect those of the United States Government or any agency thereof or The Regents of the University of California and shall not be used for advertising or product endorsement purposes. 


\section{Design and Operations at the National Tritium Labelling Facility}

Hiromi Morimoto and Philip G.Williams

National Tritium Labelling Facility, Chemical Biodynamics Division, Lawrence Berkeley Laboratory, University of California, Berkeley, CA 94720, U.S.A.

This work was supported by the Biotechnology Resources Program, Division of Research Resources, U.S. National Institutes of Health under Grant P41 RR01237, through the Department of Energy under Contract DE-AC03-76SF00098. 
DESIGN AND OPERATIONS AT THE NATIONAL TRITIUM LABEIIING FACILITY

\author{
Hiromi Morimoto and Philip G.Williams \\ National Tritium Labelling Facility, Chemical Biodynamics Division \\ Lawrence Berkeley Laboratory, University of Calffornia \\ Berkeley, California 94720 . \\ Phone (510) 486-4373, Facsimile (510) 486-4877
}

\begin{abstract}
The National Tritium Labelling Facility (NTLF) is a multipurpose facility engaged in tritium labelling research.l It offers to the biomedical research community a fully equipped laboratory for the synthesis and analysis of tritium labelled compounds. The design of the tritiation system, its operations and some labeling techniques are presented.
\end{abstract}

\section{INTRODUCTION}

The National Tritium Labelling Facility was established at Lawrence Berkeley Laboratory in 1982 and is funded by the National Institutes of Health. Its aims are to investigate and promote tritium labeling and analysis, to provide a high level labelling facility for long term collaborative projects, to provide a tritium labelling service to the biomedical community, and to educate and train investigators in the safe use of tritium.

\section{TRITIUM LABORATORY AND OPERATIONS}

The tritiation laboratory is a $5 \times 8 \mathrm{~m}$ room equipped with a central tritium source box, flanked by two tritiation reaction manifold boxes, each accessible via a pass-through window to its own workup box. Exhaust air from the workboxes is passed through a $10 \times 24 \mathrm{~cm}$ column of 40 mesh silica gel to adsorb tritiated water. At a flow rate of 0.28 $\mathrm{m}^{3} / \mathrm{min}$, this column retains tritiated water for approximately one hour before break-through. 2 After passing through the silica gel, the total effluent from the workboxes is exhausted to a common high flow stack $\left(283 \mathrm{~m}^{3} / \mathrm{min}, 10,000 \mathrm{cfm}\right)$. A diagram outlining airflow is given in Figure 1. Both room and total stack effluent concentrations are sampled and measured by dedicated ion chambers, and recorded on a continuous strip recorder.
Inputs to four other ion chambers can be directed to the process and are used for real time process monitoring. With these six ion chambers the experimenter may independently monitor tritium concentration in the room, in total effluent, and in two workboxes before and after removal of tritiated water by the columns of silica gel.

Tritium gas is purchased from EG\&G Mound Applied Technologies, Miamisburg, Ohio, in 10,000 Curie lots (ca. $1 \mathrm{~g}$ ), bound as UT 3 on a uranium bed. It is liberated, measured, and transferred onto a smaller uranium bed (capacity 25,000 C1, see Figure 2) for storage. Before use, the radiolysis product of tritium, ${ }^{3} \mathrm{He}$, is evacuated from the container while it is at room temperature. Heating of the bed to $350^{\circ} \mathrm{C}$ causes desorption of the tritium gas; cooling of the bed to room temperature causes rapid readsorption.

The tritium gas liberated by heating the $\mathrm{UT}_{3}$ bed is passed into the tritiation system (Figure 3 ). This system is an all stainless steel manifold, comprised of welded $6.35 \mathrm{~mm}(0.25$ inch) 316 stainless steel tubing $(1.65 \mathrm{~mm}$ or 0.065 inch wall), and $6.35 \mathrm{~mm}$ stainless steel Nupro bellows valves. It has connections to inert gases, to a tritium-hydrogen mixture, and to two reaction ports for tritium chemistry. The standard Nupro valve tips have been replaced with stainless steel tips, and the ring gaskets replaced by flat copper gaskets. The tritiation system is modular in design to expedite replacement of worn or non-functional parts, and the modules are connected by Cajon VCR fittings. Vacuum is maintained by two turbo-molezular pumps, and by three oil free pumps, each of the latter having diaphragm and molecular drag stages. The turbomolecular pumps are calibrated with Pirani gauges. 
For tritiation reactions, tritium is used in the form of tritium gas, as highly tritiated water $\left(\mathrm{T}_{2} \mathrm{O}\right)$, or as other useful labelling reagents. Accordingly, the tritium trapping system must take account of tritium in all these physical and chemical forms.

Tritium that remains unused during chemical reactions is trapped and recovered during a multistage process (Eigure 4). First the reaction flask is frozen in liquid nitrogen to remove tritiated water and other solvents from the gas phase, and the free tritium gas is adsorbed onto a charcoal bed held at - $196^{\circ} \mathrm{C}$. The capacity of cold, 14 mesh, activated cocoanut charcoal (Fisher Scientific) for adsorption of hydrogen gas is very large: in this case $3 \mathrm{~g}$ of charcoal at liquid nitrogen temperature adsorbs $270 \mathrm{~cm}^{3}$ of $\mathrm{H}_{2}$, the equivalent of ca. $700 \mathrm{Ci}$ of tritium gas. Note that in preliminary studies with $\mathrm{H}_{2}$, evacuation of the cooled charcoal container caused removal of approximately one third of the adsorbed hydrogen. In the second stage of $\mathrm{T}_{2}$ recovery the charcoal bed is isolated from the tritiation vessel and warmed to room temperature. This results in complete desorption of the tritium gas, which is then adsorbed onto the secondary uranium bed. Our initial studies show that more than $90 \%$ of tritium from reactions may be recovered in this manner, and captured on the secondary uranium bed (U bed $B$ ). This tritium is sent to EG\&G Mound Applied Technologies for purification and reuse as $100 \% \mathrm{~T}_{2}$ gas.

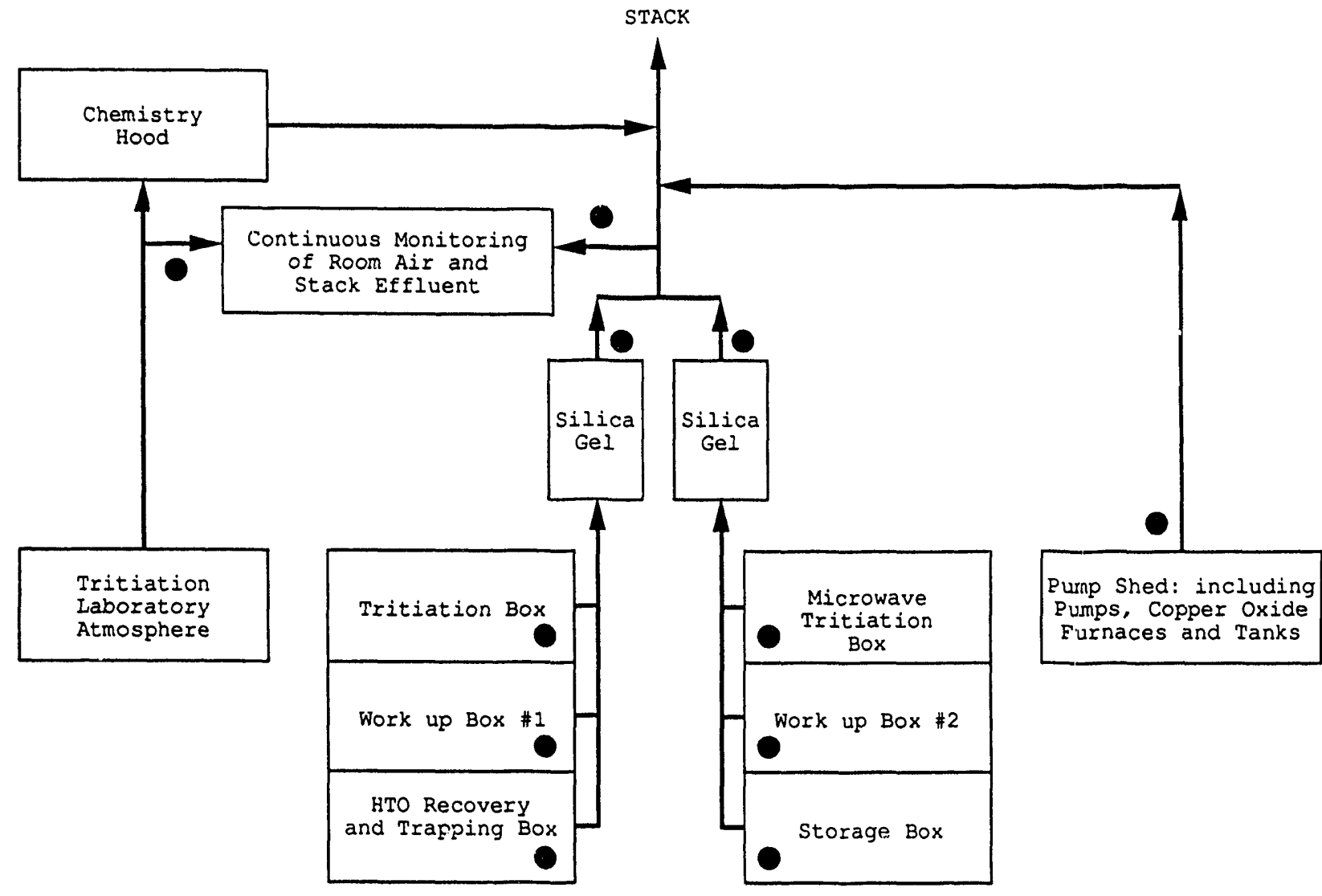

Figure i: Schematic of the airflow and monitoring points in the labelling laboratory at the NTIF. Monitoring points are indicated by filled circles. The tritium level in the laboratory air and in the stack effluent are continuously recorded on a strip chart. 


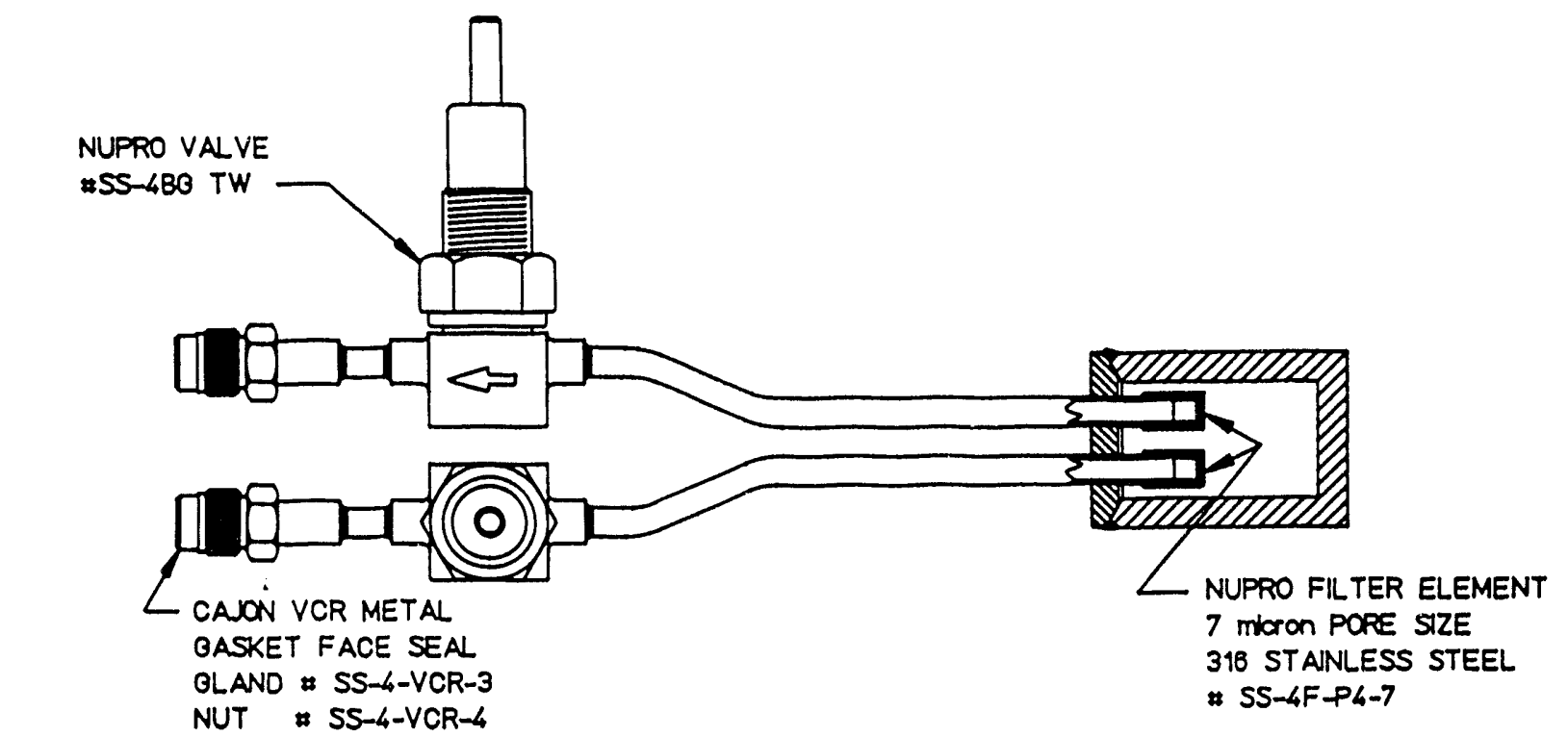

Figure 2: Uranium bed for storage of tritium as UT3. The bed contains approximately $70 \mathrm{~g}$ of Uranium, with a capacity of $\mathrm{Ca} .25,000 \mathrm{Cl}$, but is never filled beyond $15,000 \mathrm{Ci}$.

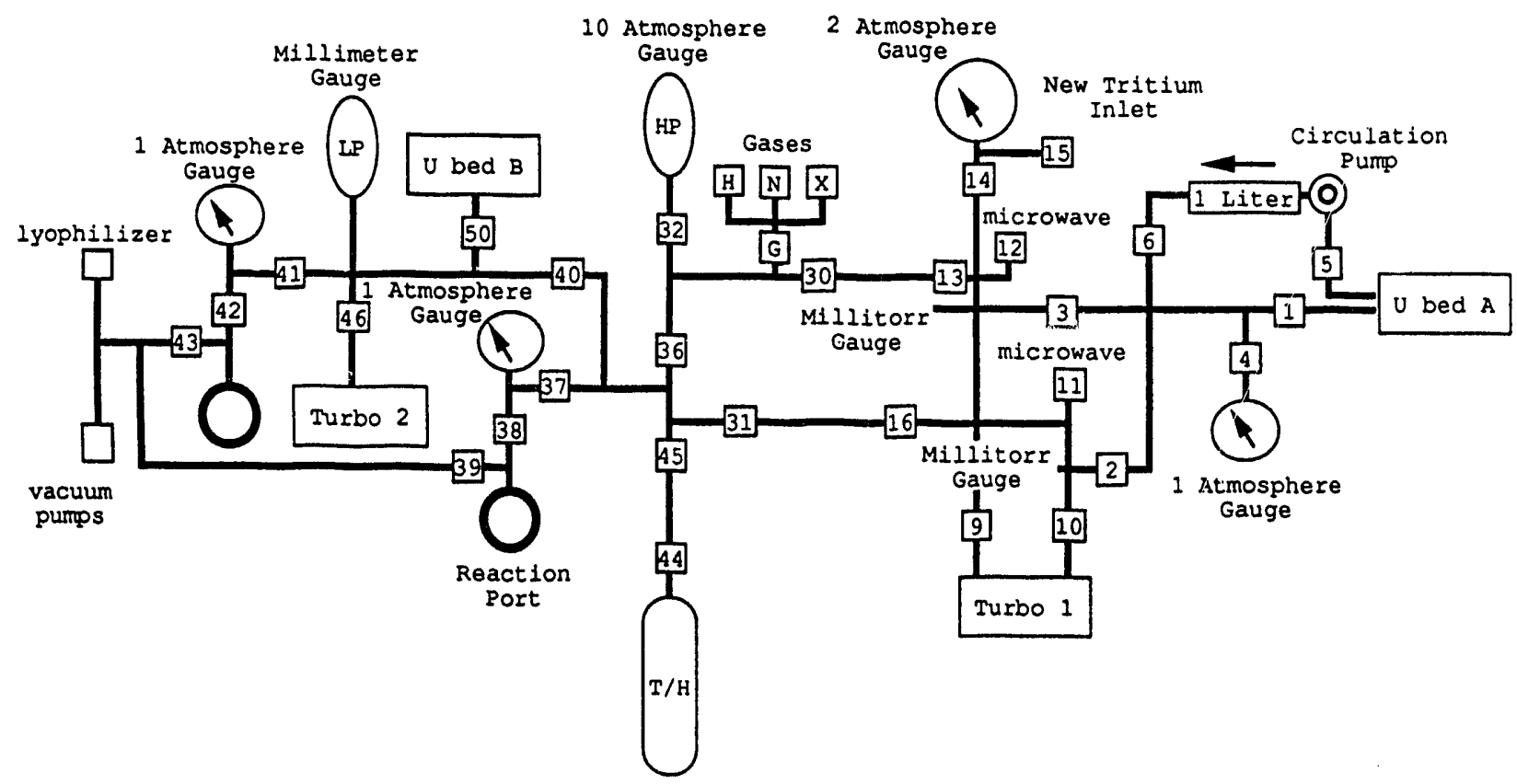

Figure 3: Components of the catalytic tritiation vacuum manifold. The system is designed to receive new tritium through valve 25 , to a known volume and pressure. This tritium is stored on U-bed $A$, and after use is recovered on U-bed $B$. 


\section{WASTE HANDIING}

The waste tritiated water, solvents, and other reactants are condensed in a liquid nitrogen cooled trap, then the gas stream is passed to the tritium trapping system. This is a duplicative system that allows regeneration of one loop while the other is being used. After the gas stream is collected in a $0.05 \mathrm{~m}^{3}$ cylinder, overnight recirculation of the cylinder contents through a copper oxide tube heated to $600^{\circ} \mathrm{C}$ converts any gas to tritiated water, and this HTO is condensed by means of an in-line Dewar cooled to $-30^{\circ} \mathrm{C}$.

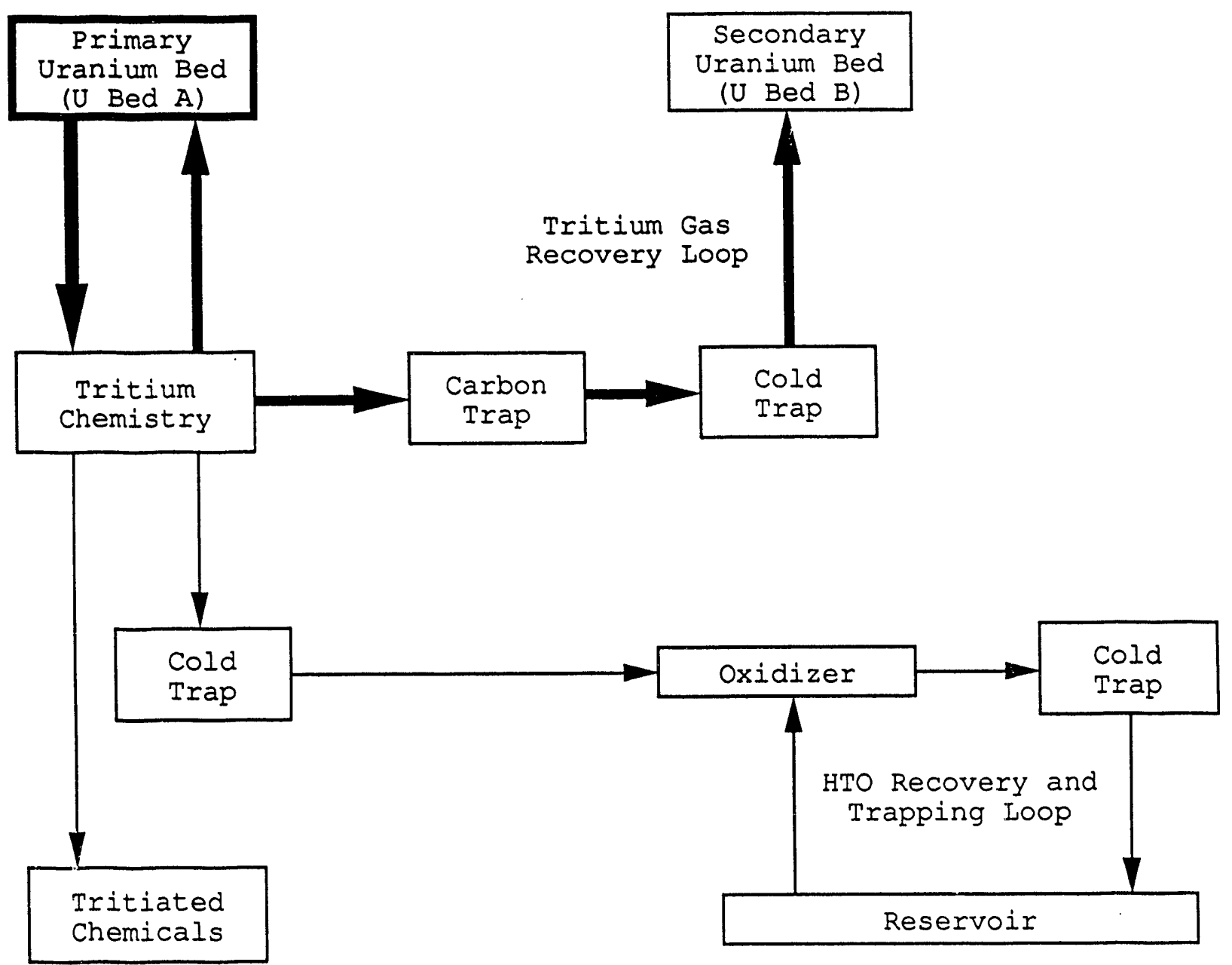

The requirements for waste disposal are thus limited to low level waste in the form of tritiated water, solvent and side products. The tritiated water from the recirculation system is of too low a level and quantity for reuse.

The change over from oil vane pumps to turbo-molecular pumps has eliminated the large reservoir of volatile tritium in oil as a potential source of tritium release, and the necessity for disposal waste. of highly tritiated pump oil as mixed 


\section{LABELIING CHEMISTRY AND ANALYSIS}

Tritium labelling to high specific activity (Table 1) has been limited primarily to addition of tritium to double bonds, and to tritiodehalogen. ation. Recently the NTLF has developed new tritide reagents at full specific activity, ${ }^{3}$ i.e. Iithium triethylborotritide (Supertritide), lithium tri-secbutyl borotritide (Selectride), and lithium aluminium tritide (IIAlT4). These have been shown to be selective yet highly reactive reagents, transferring their full specific activity to the products.

In addition to the development of labelling reagents and methodologies, 3-6 the NTLF offers the biomedical community a fully equipped and safe laboratory for the synthesis of tritium labelled chemicals. Since its inception in 1982 the Facility has hosted 122 visits by 104 scientists who have labelled 249 compounds for biomedical research. Also, the NTLF staff conduct long term collaborative projects such as the direct measurement of acid or base catalyzed exchange rates in a mixture of compounds, 7,8 the measurement of the swain-schaad exponent for the base catalyzed enolization of acetone, 9 and the interaction of ligands with proteins such as maltose binding protein 10 and $\alpha-$ chymotrypsin.11

\section{CONCIUSION}

The NTLF is a unique facility that promotes the use and analysis of tritium. It offers its expertise and technology for tritium labelling of chemicals in a safe and well equipped laboratory. Its multipurpose program provides a User service facility, engages in long term collaborative projects, and has developed a number of new labelling methods.

\section{ACKNOWIEDGEMENTS}

This research is supported by the Biotechnology Resources Program, Division of Research Resources, National Institutes of Health under Grant P4I RR01237, through the Department of Energy under Contract DE-AC03-76SF00098.

TABIE 1: Reagents, Precursors, Products and Specific Activities for Common Tritium Labelling Techniques.

\begin{tabular}{|c|c|c|c|}
\hline REAGENT & PRECURSOR & PRODUCT & $\begin{array}{c}\text { SPECIFIC ACTIVITY } \\
(\mathrm{Ci} / \mathrm{mmole})\end{array}$ \\
\hline Tritium gas & $\begin{array}{l}\text { unsaturated } \\
\text { aryl halides } \\
\text { sugars } \\
\text { benzylic compounds }\end{array}$ & $\begin{array}{l}\text { saturated } \\
\text { dehalogenated } \\
\mathrm{C}-1 \text { labelled } \\
\text { benzylic-3H }\end{array}$ & $\begin{array}{c}57 \\
28 \\
3-15 \\
3-15\end{array}$ \\
\hline Tritide reagents ${ }^{3}$ & $\begin{array}{l}\text { esters } \\
\text { epoxides } \\
\text { aldehydes } \\
\text { amides } \\
\text { aryl \& alkyl halides }\end{array}$ & $\begin{array}{l}\text { alcohols } \\
\text { amines } \\
\text { dehalogenated }\end{array}$ & $28-57$ \\
\hline Methylene diiodide 4 & unsaturated & cyclopropyl & Low \\
\hline Methyl iodide 5 & nor-precursor & methylated & $60-80$ \\
\hline Tritiated water $6, \$$ & $\begin{array}{l}\text { exchangeable } \\
\text { lithiated }\end{array}$ & exchanged & up to 25 \\
\hline
\end{tabular}

5 Tritiated water may be formed by the reaction of tritium gas and $\mathrm{PtO}_{2}$. $\mathrm{NMR}$ analysis of a reaction using 22 moles of $\mathrm{PtO}_{2}$, showed that the three water species were formed in the following ratio; $\mathrm{T}_{2} \mathrm{O} / \mathrm{HTO} / \mathrm{H}_{2} \mathrm{O}=67 / 23 / 10$. The calculated specific activity of the tritiated water was $42.1 \mathrm{Ci} / \mathrm{mmol}\left(\mathrm{T}_{2} \mathrm{O}=57.5 \mathrm{Ci} / \mathrm{mmol}\right)$, or 738 of the maximum theoretical level. 


\section{REEERENCES}

1. A.M. DORSKY, H. MORIMOTO, $M$. SALJOUGHIAN, P.G. WILIIAMS, and H. RAPOPORT, "An Introduction to the National Tritium Labeling Facility", Synthesis and Aoplications of Isotopically labelled compounds 1988 (Prec. Thind Int. Symo, Innsbruck), T.A. Baillie and J.R. Jones (Eds.), Elsevier: Amsterdam (1989), 541-544.

2. R.G. AUNE, H.P. CANTELOW, and R.L. BOITIN, "Practical Control of Tritiated Water Vapor by Silica Gel and of Tritium Gas by Use of a Purging Device", Tritium, A.A. Moghissi and M.W. Carter (Eds.), Messenger Graphics: Phoenix (1971), 749757 .

3. H. ANDRES, H. MORIMOTO, and P.G. WILLIAMS, "Preparation and Use of LiEt $3 B T$ and $\mathrm{LiAlT}_{4}$ at Maximum Specific Activity", $\mathrm{I}$ chem. Soc, chem. Commun., 627-628 (1990).

4. M. SALJOUGHIAN, H. MORIMOTO, P.G. WILIIAMS, and N. DEMELLO, "Tritiated Methylene Dilodide: $A$ New Tritium Labelling Reagent", I chem. Soc, chem. cemmun, 1652-1653 (1990).

5. M. SALJOUGHIAN, $H$, MORIMOTO, and P.G. WILIIAMS, "A General Synthesis of High Specific Activity Tritiomethyl Iodide", I. Chem Soc. Perkin Trans.1, 1803-1808 (1990).
6. U. PLIEß, and J. RÖMER, "Procedure for the Preparation of Tritiated Water", GDR Patent $248680 / 8(08 \mathrm{Feb} .1983)$.

7. R.E. DIXON, A. STREITWIESER, P.G. WILIIAMS, and P.E. EATON, "The Kinetic Acidity of Cubane", I. Am. Chem. Sec., $113,357-358$ (1991).

8. R.E. DIXON, P.G. WILIIAMS, M. SALJOUGHIAN, M.A. LONG, and A. STREITWIESER, "Direct Determination of Proton Exchange Kinetics by $320 \mathrm{MHz}$ Tritium NMR Spectroscopy", Magn. Resen. chem., 29, 509-512 (1991).

9. C.H. ARROWSMITH, I. BALTZER, A.J. KRESGE, M.F. POWELL, and Y.S. TANG, "Tritium Isotope Effects on Carbon-13 NMR Chemical shifts", I_Am. chem.Soc., 108, 1356-1357 (1986).

10. K. GEHRING, P.G. WILIIAMS, J.G. PELTON, H. MORIMOTO, and D.E. WEMMER, "Tritium NMR Spectroscopy of Iigand Binding to Maltose Binding Protein", Biechemistry, 30, 5524-5531 (1991).

11. T.M. O'CONNELL, J.T. GERIG, and P.G. WILLIAMS, "Two Dimensional Tritium-Proton Nuclear Overhauser Effects in Proteins", J. Chem. Soc., Chem. Commun., 1502-1503 (1990). 
